\title{
Anti-angiogenesis target therapy for advanced osteosarcoma (Review)
}

\author{
LU XIE, TAO JI and WEI GUO \\ Musculoskeletal Tumor Center, Peking University People's Hospital, Beijing 100044, P.R. China
}

Received February 4, 2017; Accepted June 12, 2017

DOI: $10.3892 /$ or.2017.5735

\begin{abstract}
Osteosarcomas (OS), especially those with metastatic or unresectable disease, have limited treatment options. The greatest advancement in treatments occurred in the 1980s when multi-agent chemotherapy, including doxorubicin, cisplatin, high-dose methotrexate, and, in some regimens, ifosfamide, was demonstrated to improve overall survival compared with surgery alone. However, standard chemotherapeutic options have been limited by poor response rates in patients with relapsed or advanced cases. It has been reported that VEGFR expression correlates with the outcome of patients with osteosarcoma and circulating VEGF level has been associated with the development of lung metastasis. At present, it seems to us that progress has not been made since Grignani reported a phase II cohort trial of sorafenib and sorafenib combined with everolimus for advanced osteosarcoma, which, in a sense, have become a milestone as a second-line therapy for osteosarcoma. Although the recognization of muramyltripepetide phosphatidyl-ethanolamine has made some progress based on its combination with standard chemotherapy, its effect on refractory cases is controversial. Personalized comprehensive molecular profiling of high-risk osteosarcoma up to now has not changed the therapeutic prospect of advanced osteosarcoma significantly. Thus, how far have we moved forward and what therapeutic strategy should we prefer for anti-angiogenesis therapy? This review provides an overview of the most updated anti-angiogenesis therapy in OS and discusses some clinical options in order to maintain or even improve progression-free survival.
\end{abstract}

\section{Contents}

1. Introduction

2. Tumor angiogenesis and anti-angiogenesis therapy in osteosarcoma

Correspondence to: Professor Wei Guo, Musculoskeletal Tumor Center, Peking University People's Hospital, Beijing 100044, P.R. China E-mail: bonetumor@163.com

Key words: osteosarcoma, anti-angiogenesis therapy, tyrosine kinase inhibitors, clinical application
3. Clinical trials of anti-angiogenesis of osteosarcoma

4. Moving forward, what stops us

5. Strategy for advanced osteosarcoma in the era of targeted therapy

6. Conclusion

\section{Introduction}

Osteosarcoma is a malignant tumor of mesenchymal origin and primarily occurs in children, adolescents, and young adults. This pleiomorphic tumor of the bone, based on animal model systems (1), depends on new blood vessel development, also known as angiogenesis, for tumor growth and metastasis. Although modern multimodality treatment has significantly improved tumor resectability and the long-term outcome of these patients, $25-35 \%$ of patients with initially non-metastatic disease subsequently develop metastasis and this remains the major cause of death (2). At the same time, axial skeletal osteosarcoma preliminarily responds poorly to chemotherapy and has been proven to have an even more dismal prognosis (3). From the review of van Maldegem et al (2) and Lagmay et al (4), we concluded that in the past two decades, published phase I/II clinical trials on chemotherapy for osteosarcoma failed to make significant progress in refractory cases. With the study of oncogenesis and pathobiological behavior of osteosarcoma (1), we know that new blood vessel formation (angiogenesis) is fundamental to tumor growth, invasion, and metastatic dissemination.

Several groups have evaluated tumor micro-vessel density and outcome in osteosarcoma (5-7). Expression of VEGF has been suggested as a means of evaluating the prognostic importance of angiogenesis in osteosarcoma (8). Monotherapy with second-generation broad-spectrum VEGF receptor tyrosine kinase inhibitors (TKIs) in sarcoma has now become an area of active research and application beyond gastrointestinal stromal tumors (GISTs). Within all of those preclinical experiments and clinical trials $(6,9-13)$, the milestone of the treatment on advanced osteosarcoma should count on the application of anti-angiogenesis TKIs sorafenib on refractory cases from the Italian Sarcoma Group (13), which officially raised the 4-month progression-free survival (PFS) from $<30-46 \%$ for the first time. However, things had seemed not to change as dramatically as was expected since then. The main hurdle that researchers need to get over should be sensitivity and drug-resistance (14). 
The goals of this review are: a) to review representative agents in in vitro and in vivo experiments that showed promise for osteosarcoma based on anti-angiogenesis therapy; b) to summarize the current phase I and II trials of anti-angiogenensis therapies that have been explored in advanced osteosarcoma patients; and c) to focus on targeting the action towards VEGFR and to discuss current hurdles and future perspectives.

\section{Tumor angiogenesis and anti-angiogenesis therapy in osteosarcoma}

Tumor angiogenesis and optional treatments. Angiogenesis is the process of new blood vessel development, which is critical in both physiological development and pathological processes, such as tumor progression, wound healing, and cardiovascular, inflammatory, ischemic, and infectious diseases (15). In response to hypoxia, tumor tissues produce and release angiogenic growth factors, such as vasculo-endothelial growth factor (VEGF), the acidic and basic fibroblast growth factors (aFGF and bFGF), and the platelet-derived endothelial cell growth factor (PD-ECGF) to recruit new blood vessels by angiogenesis and vasculogenesis (16). It is now widely accepted that both mutations of oncogenes and tumor suppressor genes lead to the switch into an angiogenic tumor. According to Gorlick et al (1), osteosarcoma has complex unbalanced karotypes and with alterations of the p53 and retinoblastoma pathways in most cases, thus the vasculature playing an intimate role in the progression of the pathologic development of osteosarcoma.

VEGF is a key tumor-derived angiogenic factor that has multiple functions, including stimulation of angiogenesis, vasculogenesis, inflammation, and vascular permeability, which constitutes the most important signaling pathways in tumor angiogenesis (7). According to Niu et al (16), the whole VEGF family has been identified to comprise 8 members with a common VEGF homology domain: VEGF-A, VEGF-B, VEGF-C, VEGF-D, VEGF-E, VEGF-F, and placenta growth factor (PIGF)-1 and -2. As shown in Fig. 1, VEGFs signal through 3 tyrosine kinase receptors, known as Flt-1 (VEGFR-1), Flk-1/KDR (VEGFR-2), and VEGFR-3 (17), which were previously thought to be predominantly expressed by endothelial cells, but in actual fact are also in sarcoma cell lines with limited study (18-21). It has been reported that both VEGFR-1 and -2 can promote angiogenesis and VEGFR-3 stimulation leads to lymphangiogenesis (22).

There is a general consensus that VEGFR-2 is the dominant receptor in mediating the pro-angiogenic functions of VEGF-A and this pathway has been prioritized for the development of antiangiogenic therapies $(16,23)$. Though VEGFR-1 has a 10-fold higher binding affinity for VEGF-A, its activation has less impact on the activation of intracellular signaling intermediates than VEGFR-2 (23).

Recognition of the VEGF pathway as a key regulator of angiogenesis has led to the development of several VEGFtargeted agents, including agents that prevent VEGF-A binding to its receptors (24), antibodies that directly block VEGFR-2 (25), and small molecules that inhibit the kinase activity of VEGFR-2 thereby block growth factor signaling (26). Some of them have been approved by the FDA of the US for clinical applications (16). Previous representative anti-angiogenic compounds (10,27-39)

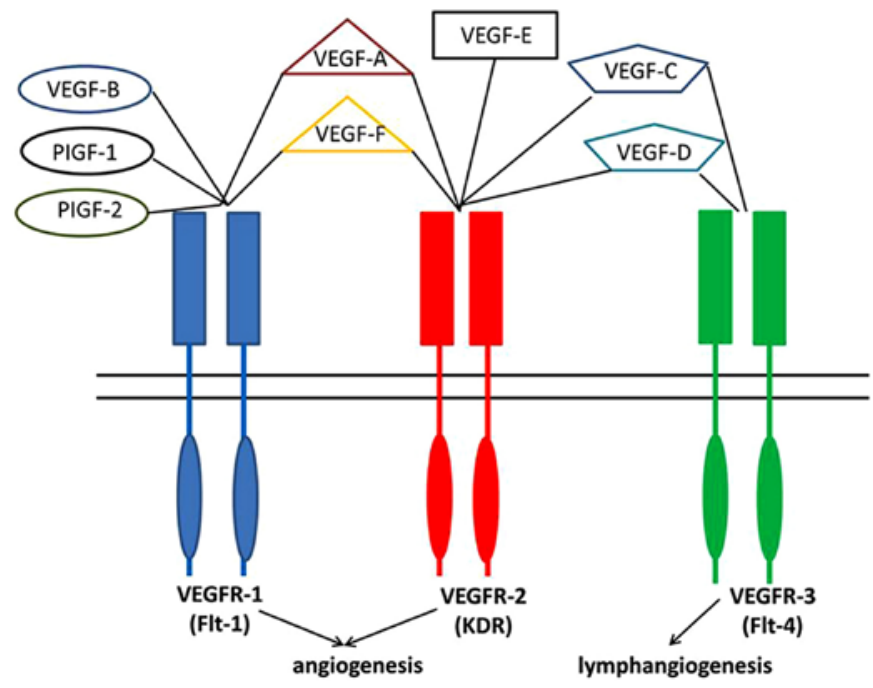

Figure 1. Common subtypes of VEGF and VEGFR and their main function.

are summarized in Table I with median inhibition concentration $\left(\mathrm{IC}_{50}\right)$ noted for comparison.

Moreover, Broadhead et al (40-43) repeatedly reported that pigment epithelium-derived factor (PEDF), co-localized with VEGF in tumor tissue, was probably important in the fine-tuning of tumor vasculature and aggression. However, the clinical application of this agent is under investigation (NCT00702494).

Fundamental study of angiogenesis in osteosarcoma and other related cellular signaling pathways. Geller and Gorlick (44) reviewed HER-2 targeted treatment of osteosarcoma. The results showed that HER-2 expression as a prognostic factor in osteosarcoma remained controversial and a comparison of the results is difficult because of variables, including the handling and preparation of material, tissue heterogeneity, fixation techniques, storage conditions, antibody characteristics, scoring scheme, and staining interpretation due to single-institution, retrospective studies that were limited in size. Abdeen et al (45) stated in 2009 that there was a negative correlation between VEGFR-3 and both overall survival and event-free survival of osteosarcoma, and VEGF-B was correlated with a poor histologic response to chemotherapy. In 2011, Yang et al (46) reported that vascular endothelial growth factor (VEGF) pathway genes collectively were amplified, and alterations of this pathway were validated by fluorescence in situ hybridization (FISH) and immunohistochemistry analyses in 58 formalin-fixed, paraffin-embedded osteosarcoma archival tissues that had clinical follow-up information. Lammli et al (47) in 2012 demonstrated that there was a significant positive correlation between VEGF expression and tumor stages among these cases $(\mathrm{P}<0.01)$. The data also suggested a higher cancer recurrence and more frequent cases of remote metastasis in the high-VEGF group compared to the low-VEGF group. The expression of VEGF has been used as a more objective means of evaluating the prognostic importance of angiogenesis in osteosarcoma. One group found that $63 \%$ of osteosarcoma samples demonstrated VEGF immunohistochemical staining in tumor cells (8). 
Table I. Summary of the mechanisms of action of the anti-angiogenic compounds in preclinical experiments of osteosarcoma.

\begin{tabular}{|c|c|c|c|}
\hline Compound & Mechanism & Target $\left(\mathrm{IC}_{50}, \mathrm{nM}\right)$ & Refs. \\
\hline Endostatin & $\begin{array}{l}\text { Internal fragment of } \\
\text { the carboxy-terminus } \\
\text { of collagen XVIII }\end{array}$ & $\begin{array}{l}\text { A broad-spectrum } \\
\text { endogenous } \\
\text { antiangiogenic molecule }\end{array}$ & $(62,74)$ \\
\hline MMPs & $\begin{array}{l}\text { A family of enzymes that } \\
\text { proteolytically degrade various } \\
\text { components of the ECM }\end{array}$ & Non-specific & (74) \\
\hline PEDF & $\begin{array}{l}\text { A secreted glycoprotein that } \\
\text { is a non-inhibitory member } \\
\text { of the serine protease inhibitor }\end{array}$ & Non-specific & $(47-52,74)$ \\
\hline Bevacizumab & A humanized anti-VEGF antibody & VEGF-A $\left(\mathrm{ED}_{50}=50 \mathrm{ng} / \mathrm{ml}\right)$ & $(31,35,40,98,114-116)$ \\
\hline Pegaptanib & An anti-VEGF RNA aptamer & $\operatorname{VEGF}_{165}(0.75-1.4)$ & (66) \\
\hline $\begin{array}{l}\text { VEGF Trap } \\
\text { (Aflibercept) }\end{array}$ & A soluble receptor to VEGF & $\begin{array}{l}\text { VEGF-A and VEGF-B }(0.001) \text {, } \\
\text { placental growth factor }(0.045)\end{array}$ & $(67)$ \\
\hline Sorafenib & TKIs & $\begin{array}{l}\text { VEGFR-2 (90), Raf-1 (6), B-Raf (22), } \\
\text { c-kit (68), FGFR-1 (580), FLT-3 (58) }\end{array}$ & $(15,16,35,70,71,86)$ \\
\hline Sunitinib & TKIs & $\begin{array}{l}\text { VEGFR-1 (2), VEGFR-2 (80), } \\
\text { VEGFR-3 (17), PDGFR- } \beta \text { (2) }\end{array}$ & $(43,45,92)$ \\
\hline Cediranib & TKIs & VEGFR-2 (<1), VEGFR-1 (5), & $(13,42)$ \\
\hline Pazopanib & TKIs & $\begin{array}{l}\text { VEGFR-3 ( } \leq 3), \text { VEGFR-1 (10), } \\
\text { VEGFR-2 (30), VEGFR-3 (47), } \\
\text { PDGFR- } \beta \text { (84), c-kit (140), FGFR (74), }\end{array}$ & $(37-39,72)$ \\
\hline Ramucirumab & $\begin{array}{l}\text { A fully humanized } \\
\text { MAb targeting to the } \\
\text { extracellular VEGF-binding } \\
\text { domain of VEGFR-2 }\end{array}$ & c-fms (146), VEGFR-2 (0.05) & $(73)$ \\
\hline Dasatinib & TKIs & BCR/ABL $(<1)$, c-kit (79), Src (0.8) & (14) \\
\hline Regorafenib & TKIs & $\begin{array}{l}\text { VEGFR-1 (13), VEGFR-2 (4.2), } \\
\text { VEGFR-3 (46), PDGFR- } \beta \text { (22), } \\
\text { c-kit (7), RET (1.5), Raf-1 (2.5) }\end{array}$ & (74) \\
\hline Everolimus & mTOR signaling pathways & FKBP12 (1.6-2.4) & $(15,87,124)$ \\
\hline Imatinib & TKIs & v-Abl (600), c-kit (100), PDGFR (100) & $(54)$ \\
\hline
\end{tabular}

$\mathrm{IC}_{50}$, median inhibition concentration; concentration that reduces the effect by 50\%. MMPs, metalloproteinases; PEDF, pigment epitheliumderived factor; ECM, extracellular matrix; TKIs, tyrosine kinase inhibitors; mTOR, mammalian target of rapamycin.

In 2013, Chen et al (48) completed a meta-analysis of published studies and performed a systematic review to provide a comprehensive assessment of the prognostic role of VEGF expression. They included 12 studies with a total of 559 osteosarcoma patients in the systematic review and meta-analysis. Compared with osteosarcoma patients with low or negative VEGF expression, patients with high VEGF expression were obviously associated with lower disease-free survival $\left(\mathrm{OR}=0.25,95 \% \mathrm{CI} 0.11-0.58, \mathrm{P}=0.001, \mathrm{I}^{2}=56.4 \%\right)$. In addition, patients with high VEGF expression were obviously associated with lower overall survival $(\mathrm{OR}=0.22,95 \%$ CI $0.13-0.35, \mathrm{P}<0.001, \mathrm{I}^{2}=0.0 \%$ ). Therefore, the findings from this systematic review suggested that VEGF expression was an effective biomarker of prognosis in patients with osteosarcoma. However, different from soft tissue sarcoma (49), osteosarcoma has not been classified by which subtypes of VEGFR expression correlate with prognosis. Kampmann et al (49) reported in 2015 that the high expression of VEGFR1-3 and PDGFR- $\beta$ was significantly correlated with higher grading (G2 vs. G3, $\mathrm{P}<0.05)$, and high VEGFR-2 was significantly correlated with decreased patient survival $(\mathrm{P}<0.001)$.

According to Aurby et al (50), angiogenesis inhibitors can be divided into 2 classes: direct inhibitors and indirect inhibitors. Direct inhibitors target endothelial cells by 
arresting proliferation and migration of these cells or by inducing their apoptosis. Indirect angiogenesis inhibitors act on the signaling pathways induced by angiogenic stimuli, by sequestering the angiogenic factors secreted by tumor cells, or by blocking the signal transduction pathways that are activated when binding factors meet their receptors on endothelial cells. The first direct inhibitor was endostatin, which was an internal fragment of the carboxy-terminus of collagen XVIII (51). It is a paradigm of a broad-spectrum endogenous anti-angiogenic molecule, through which the results of in vitro experiments are satisfactory. However, methods of resolubilization gave very low yields of active proteins, which makes it hard to be a mature pharmaceutical and obstructs its further development. Bevacizumab (52) neutralizes all isoforms of human VEGF and inhibits VEGFinduced proliferation of endothelial cells in vitro with an $\mathrm{ED}_{50}$ of approximately $50 \mathrm{ng} / \mathrm{ml}$. It was tested in combination with several chemotherapeutic drugs, such as doxorubicin, topotecan, paclitaxel, and docetaxel, showing an additive antitumor effect $(28,53,54)$. However, as for osteosarcoma, clinical application did not prove as effective as the experiments (53). With innovation from the VEGF-A aptamer (55) to VEGF trap (56), more focus has been given to the VEGFR tyrosine kinase inhibitors (TKIs) $(7,16)$.

Protein kinases are key enzymes in the regulation of various cellular processes that catalyse transfer of a phosphate group from ATP to a hydroxyl group of a serine or a threonine. Among the 90 identified genes encoding proteins with tyrosine kinase activity, 58 encode receptors divided into 20 subfamilies (57). Of these, EGFR/ErbB (class I), the receptor for insulin (class II), PDGF (class III), FGF (class IV), VEGF (class V), and HGF (MET, class VI) are strongly associated with oncological diseases (58). Unlike bevacizumab, VEGF Trap, and pegaptanib, which target extracellular VEGF, TKIs target the intracellular signaling pathways of VEGF receptors as well as a variety of receptors that rely on a tyrosine kinase component to function properly, including PDGF receptor, FMS-like tyrosine kinase 3 (FLT3), RAF, and c-KIT receptors (16). In Table I, we summarize the classic TKIs compounds in preclinical experiments for osteosarcoma and their main targeted region. Sunitinib and sorafenib share a similar mechanism of action and primarily target tumor angiogenesis by inhibiting a variety of tyrosine kinases $(36,59,60)$. Pazopanib is an oral, second-generation multi-targeted tyrosine kinase inhibitor targeting VEGF-1, -2 , and -3 receptors, PDGF- $\alpha$ and $-\beta$ receptors, and c-kit, which exhibited good potency against all of the human VEGFRs and closely related tyrosine receptor kinases in vitro $(30,31,61)$. Besides TKIs, antibodies blocking VEGFR2 have also been developed (62).

In addition to anti-angiogenesis drugs, there are some other cellular signaling pathways that should be mentioned as they are always used in combination with anti-angiogenesis target drugs in clinical trials of osteosarcoma. A signal transduction pathway through insulin-like growth factor (IGF) receptor signaling, which is also an attractive therapeutic target for the treatment of osteosarcoma, is the mammalian target of the rapamycin (mTOR) pathway (63). mTOR technically does not belong to anti-angiogenesis therapy according to Hanahan et al (64). Under conditions favorable for cell growth,
mTOR activates ribosomal protein translation (via S6K1) and cap-dependent translation (via eIF4E), allowing $\mathrm{G}_{1}$ to $\mathrm{S}$ phase cell cycle progression. This signal pathway was not originally activated in most sarcoma patients (65), but after using antiangiogenesis TKIs for a while, many sarcomas show secondary activated pathway, which makes this target as a supplement to TKIs for long-term use (66). At the same time, the involvement of the IGF/IGF1-R axis in tumorigenesis makes it an attractive target for anticancer therapeutics, especially in Ewing's sarcoma (65). A human IgG1 type monoclonal antibody directed against the human IGF-IR, has been developed to antagonize IGF-IR signaling $(67,68)$.

\section{Clinical trials of anti-angiogenesis of osteosarcoma}

Current status of second-line chemotherapy for osteosarcoma. After failing standard first-line chemotherapy for osteosarcoma, patients who relapse present a more challenging treatment dilemma. In general, recurrence portends an extremely poor long-term prognosis (1). In some cases, through aggressive surgical resection of all gross disease, patients can still acquire long-term survival $(69,70)$. The choice of second-line chemotherapy and the use of investigational drugs are not standardized and the outcomes are dismal (4). van Maldegem et al (2) carried out a comprehensive analysis of published phase I/II clinical trials between 1990-2010 in osteosarcoma and Ewing's sarcoma, and it turned out that the results were not convincing for benefit and most of the time disappointing. From osteosarcoma trials they found only $8 \% \mathrm{CR}, 2.8 \% \mathrm{PR}$, and $4 \% \mathrm{SD}$. The phase II trials were mainly on second-line chemo-drugs, which contained high-intensity ifosfamide-based therapy with or without autologous peripheral blood stem cell support transplantation, etoposide, topotecan, epirubicin, and even cyclophosphamide. Lagmay et al (4) reviewed the outcome of patients with recurrent osteosarcoma enrolled in 7 phase II trials through Children's Cancer Group, Pediatric Oncology Group, and Children's Oncology Group and found that in each included trial, the drugs tested were determined to be inactive on the basis of radiographic response rates. The event-free survival for 96 patients with osteosarcoma with measurable disease was $12 \%$ at 4 months (95\% CI, 6\% to 19\%), with treatments that included drugs such as docetaxel, topotecan, irinotecan, rebeccamycin, oxaliplatin, xabepilone, and even imatinib, aerosolized granulocytemacrophage colony-stimulating factor (GM-CSF) from 1997 to 2007 (4). From these data, we can establish a baseline of the expected time for disease progression in patients with relapsed osteosarcoma.

Phase I and II trials of target therapy for osteosarcoma. In actual fact, it is difficult to carry out trials in advanced osteosarcoma, mainly because of the problems of recruiting enough eligible patients for the trials. In search of phase I and II anti-angiogenesis trials of osteosarcoma, we identified 35 phase I/II trials for osteogenic sarcoma that were published between 2005 and 2016. Unfortunately, the phase I trials for general sarcoma may not be complete because many trials do not distinguish between different subtypes of osteogenic sarcoma. However, different kinds of sarcomas have totally different biological behaviors, such as osteosarcoma, Ewing's 
Table II. Clinical results of phase I trial with currently available anti-angiogenesis therapy on osteosarcoma.

\begin{tabular}{|c|c|c|c|c|c|c|c|}
\hline Drug & Targets & $\begin{array}{l}\text { Combined } \\
\text { with } \\
\text { chemotherapy }\end{array}$ & $\begin{array}{l}\text { The first } \\
\text { author's } \\
\text { surname }\end{array}$ & $\begin{array}{c}\text { Year of } \\
\text { publication }\end{array}$ & $\begin{array}{c}\text { Trial } \\
\text { sponsor }\end{array}$ & $\begin{array}{l}\text { Clinical } \\
\text { results }\end{array}$ & Refs. \\
\hline Gefitinib & EGFR & No & Daw & 2005 & $\mathrm{COG}$ & 6/6 PD & (44) \\
\hline $\begin{array}{l}\text { Everolimus; } \\
\text { Figitumumab }\end{array}$ & $\begin{array}{l}\text { mTOR; } \\
\text { IGF-IR }\end{array}$ & No & Quek & 2010 & $\begin{array}{l}\text { Novartis } \\
\text { and Pfizer }\end{array}$ & $3 / 3 \mathrm{SD}$ & (87) \\
\hline Cediranib & VEGFR1-3 & No & Fox & 2010 & $\mathrm{NIH}, \mathrm{NCI}$ & $1 / 4 \mathrm{PR}$ & (42) \\
\hline R1507 & IGF-IR & No & Bagatell & 2010 & $\mathrm{NIH}$ & $2 / 3 \mathrm{SD}$ & (46) \\
\hline Sunitinib & $\begin{array}{l}\text { VEGFR; PDGFR; } \\
\text { c-kit; Flt3, CSF-1 } \\
\text { receptor, and RET }\end{array}$ & No & Dubios & 2011 & $\mathrm{COG}$ & $1 / 2 \mathrm{SD}$ & (43) \\
\hline Cixutumumab & IGF-IR & No & Malempati & 2012 & $\mathrm{COG}$ & 3/3 PD & (36) \\
\hline Pazopanib & VEGFR1-3; PDGFR & No & Bender & 2013 & $\mathrm{COG}$ & $1 / 4 \mathrm{SD}$ & (39) \\
\hline $\begin{array}{l}\text { Sorafenib; } \\
\text { Bevacizumab }\end{array}$ & $\begin{array}{l}\text { VEGFR-2, Raf-1, } \\
\text { B-Raf, c-kit, FGFR-1, } \\
\text { FLT-3; VEGF-A }\end{array}$ & $\begin{array}{c}\text { Low-dose } \\
\text { cyclophosphamide }\end{array}$ & Navid & 2013 & $\begin{array}{l}\text { Novartis } \\
\text { and Pfizer }\end{array}$ & $2 / 2 \mathrm{SD}$ & (35) \\
\hline
\end{tabular}

Clinical responses were defined as described in the referred studies. CBR, clinical benefit response; CR, complete response; PR, partial response; MR, minor response; SD, stable disease (for at least 8 weeks); PD, progressive disease (no response). COG, Children's Oncology Group; NIH, National Institutes of Health; NCI, National Cancer Institute; EGFR, epidermal growth factor receptor; mTOR, mammalian target of rapamycin signaling pathways; IGF-IR, type 1 insulin-like growth factor receptor; VEGFR, vascular endothelial growth factor receptor.

sarcoma, and chondrosarcoma, which all originate from bone but show totally different sensitivity to chemo-drugs. Thus, we will just focus on the results of clinical trials that specialized in osteosarcoma so as to make the comparison more meaningful. With an internet search of MEDLINE, the Embase database, the Cochrane Central Register of Controlled Trials database, the American Society of Clinical Oncology (ASCO), and the European Society for Medical Oncology (ESMO), we summarize the list of phase I and II trials in Tables II and III, which only include the data of osteosarcoma and the clinical results (11-13,27-33,35-39,53,61,67,68,71-78).

Abundant active agents had been tested for osteosarcoma patients in a small number for their availability. Geller and Gorlick (44) proposed the use of HER-2 directed therapy for a subset of patients with osteosarcoma, which in theory was an appealing idea assuming HER-2 expression was in fact associated with poor prognosis, since expression can be accurately and reproducibly identified. However, a phase II clinical trial initiated by Children's Oncology Group of trastuzumab, in addition to standard chemotherapy for patients with newly diagnosed metastatic osteosarcoma (Table III), has proven to be without significant difference when compared with the control group (30 months-EFS 32\%; 30 months-OS 50\%) (53). From the list of phase I trials (Table II), although there is a small number of patients, it seems to us that the EGFR inhibitor and the antibody against type 1 insulin-like growth factor receptor (IGF-IR) did not show similar activity in osteosarcoma as in Ewing's sarcoma $(67,68,74)$.

Most anti-angiogenesis TKIs can only keep the tumor stable rather than make it obviously shrunken, while only cediranib, which is a TKIs targeted particularly towards VEGFR2 ( IC $_{50}$ especially low, shown in Table I), had 1 refractory osteosarcoma partial response (35). Another phase I study that combined cediranib with gefitinib showed antitumor activity in patients with advanced solid tumors, including one osteosarcoma patient (37). Since we could not get detailed information for this osteosarcoma patient, it was not included in Table II. The authors also demonstrated changes in VEGF and soluble VEGFR-2 levels following treatment. These initial subgroup results, which were not as responsive as we expected, might lead to many pharmaceutical companies stopping further investigation of their phase II trials for osteosarcoma. This may be why we seem to stagnate after the sorafenib trial reported by Grignani et al $(12,13)$.

As for phase II trials, the greatest progress belonged to Italian Sarcoma Group, which held 2 cohort phase II trials with advanced osteosarcoma patients with an object response rate (ORR) of 14 and 10\%, respectively $(12,13)$. Although the addition of everolimus did not obviously change the response rate, the combination of sorafenib and everolimus significantly prolonged the duration of response from 4 months in sorafenib alone to 5 months, which has been stated to be the best treatment results in the second-line drug therapy history of osteosarcoma. However, this 45\% 6-month PFS (combination therapy) was less than the pre-specified threshold of activity (6 month PFS of $50 \%$ or greater) to be deemed worthy of a phase III trial. In addition, the toxic effects seemed to be more severe than sorafenib alone (13). Children's Oncology Group (COG) has conducted several phase II trials with cixutumumab (68), which is the insulin-like growth factor-I 
Table III. Summary of Phase II trial results of currently available anti-angiogenesis therapy for osteosarcoma.

\begin{tabular}{|c|c|c|c|c|c|c|c|c|}
\hline Drug & $\begin{array}{l}\text { Combined } \\
\text { with } \\
\text { chemotherapy }\end{array}$ & Stage & $\begin{array}{l}\text { The first } \\
\text { author's } \\
\text { last name }\end{array}$ & $\begin{array}{c}\text { Year of } \\
\text { publication }\end{array}$ & $\begin{array}{l}\text { Trial } \\
\text { sponsor }\end{array}$ & $\begin{array}{l}\text { No. of } \\
\text { patients }\end{array}$ & $\begin{array}{l}\text { Clinical } \\
\text { outcome }\end{array}$ & Refs \\
\hline Sorafenib & No & Advanced & Grignani & 2011 & $\begin{array}{l}\text { Italian } \\
\text { Sarcoma } \\
\text { Group }\end{array}$ & 35 & $\begin{array}{l}4 \text { months-PFS } 46 \% \text {; } \\
\text { DR } 4 \text { months; } \\
\text { ORR } 14 \%\end{array}$ & (16) \\
\hline Trastuzumab & $\begin{array}{l}\text { Cytotoxic } \\
\text { chemotherapy }\end{array}$ & $\begin{array}{l}\text { Newly } \\
\text { diagnosed, } \\
\text { high-grade } \\
\text { metastatic }\end{array}$ & Ebb & 2012 & $\mathrm{COG}$ & 41 & $\begin{array}{l}30 \text { months-EFS } 32 \% \text {; } \\
30 \text { months-OS } 50 \% \text {; } \\
\text { without significant } \\
\text { difference comparing } \\
\text { with control group }\end{array}$ & (64) \\
\hline Sirolimus & $\begin{array}{c}\text { Cyclo- } \\
\text { phosphamide }\end{array}$ & Advanced & Schuetze & 2012 & $\begin{array}{l}\text { Michigan } \\
\text { University }\end{array}$ & 5 & $\begin{array}{l}\text { ORR } 0 \% \text {; } \\
4 \text { months-PFS } 30 \% \\
\text { (combined with } \\
\text { other sarcoma) }\end{array}$ & (82) \\
\hline $\begin{array}{l}\text { Cixutumumab } \\
\text { and temsirolimus }\end{array}$ & No & Advanced & Schwartz & 2013 & $\begin{array}{l}\text { MSKCC } \\
\text { fund }\end{array}$ & 24 & $\begin{array}{l}\text { ORR } 13 \% \\
\text { median PFS } 6 \text { weeks }\end{array}$ & (85) \\
\hline Cixutumumab & No & Advanced & Weigel & 2014 & $\mathrm{COG}$ & 11 & $\begin{array}{l}\text { ORR } 0 \% ; \\
1 / 11 \text { SD for } \\
140 \text { days }\end{array}$ & (36) \\
\hline R1507 & No & Advanced & Pappo & 2014 & SARC & 38 & $\begin{array}{l}\text { ORR } 2.5 \% ; \\
\text { DR: } 12 \text { weeks; } \\
12 \text { weeks-PFS } 17 \%\end{array}$ & (88) \\
\hline $\begin{array}{l}\text { Sorafenib; } \\
\text { Everolimus }\end{array}$ & No & Advanced & Grignani & 2015 & $\begin{array}{l}\text { Italian } \\
\text { Sarcoma } \\
\text { Group }\end{array}$ & 38 & $\begin{array}{l}6 \text { months-PFS } 45 \% \text {; } \\
\text { DR } 5 \text { months; } \\
\text { ORR } 10 \%\end{array}$ & (15) \\
\hline $\begin{array}{l}\text { Cixutumumab; } \\
\text { Temsirolimus }\end{array}$ & No & Advanced & Wagner & 2015 & $\mathrm{COG}$ & 11 & ORR 0\% & (79) \\
\hline Dasatinib & No & Advanced & Schuetze & 2016 & SARC & 46 & $\begin{array}{l}\text { ORR } 6.5 \% ; \\
\text { DR } 5.7 \text { months; } \\
2 \text { years-OS } 15 \%\end{array}$ & (14) \\
\hline
\end{tabular}

PFS, progression-free survival; OS, overall survival; ORR, overall response rate, defined as complete responses (CRs) + partial responses (PRs) + MRs; DR, duration of response; COG, Children's Oncology Group; ACS, American Cancer Society; SARC, Sarcoma Alliance for Research Through Collaboration Study; MSKCC, Memorial Sloan-Kettering Cancer Center.

receptor (IGF-IR), since preclinical data suggested that inhibition of the IGF-IR might constitute an important therapeutic target in a variety of pediatric solid tumors, including rhabdomyosarcoma, neuroblastoma and Wilms tumor. For refractory solid tumors, there was only a sub-group analysis for osteosarcoma with the number of patients 11 in both the cixutumumab single-drug trial (67), and in combination with cixutumumab and temsirolimus in a trial (68). However, for pediatric advanced osteosarcoma, the ORR was $0 \%$ for both of the trials. With PFS and OS data unextractable in both of these trials, only 1 patient using cixutumumab alone had stable disease for 140 days (67). In 2013, Memorial SloanKettering Cancer Center (MSKCC) proceeded with a similar trial with a combination of cixutumumab and temsirolimus on refractory osteosarcoma, which showed an ORR of $13 \%$ with a median PFS of 6 weeks (74). The number of patients was 24, which showed a little more than the same trial conducted by COG of 11 (68). MSKCC included patients older than 16 years while COG included all solid tumor patients aged from 1-30 years. Due to the small sample size, we could not speculate why their results were so different. This combination therapy may need further study with a larger sample size in a randomized controlled trial to identify its effectiveness. The Sarcoma Alliance for Research Through Collaboration Study has also completed 2 trials on advanced osteosarcoma, which were respectively IGF-IR R1507 and TKI dasatinib (11,77). R1507 did not seem to be effective with an ORR of $2.5 \%$ and 12 -week-PFS of $17 \%$, while dasatinib showed an ORR of $6.5 \%$ and duration of response of 5.7 months, which indicated that BCR/ABL, c-kit, and src might not be the target 
for osteosarcoma. The Bayesian design allowed for the early termination of accrual in osteosarcoma subtypes because of the lack of drug activity (11).

\section{Moving forward, what stops us}

Resistance. For advanced osteosarcoma patients, drug sensitivity is pivotal at the beginning of therapy to help patients to establish the confidence to continue using it; however, from the observation through phase I trials, these TKIs hardly seemed to reduce the tumor size, which usually stopped investigators to open a phase II trial to explore the activity towards osteosarcoma. From the perspective of Versleijen-Jonkers et al (6), unlike chemotherapeutic agents, angiogenesis inhibitors slow or stop tumor growth rather than cause tumor shrinkage.

Up to now there was no direct evidence on which kind of TKIs have more potency to be sensitive, but we may boldly speculate that cediranib (35), which is the only drug that made refractory osteosarcoma smaller in size in a phase I trial, might be more sensitive than other TKIs for its low $\mathrm{IC}_{50}$ value towards VEGFR, especially VEGFR-2. There is a general consensus that VEGFR-2 is the dominant receptor in mediating the pro-angiogenic functions of VEGF-A, and this pathway has been prioritized for the development of antiangiogenic therapies (16). Clinical trial expression analysis of different subtypes of tyrosine kinases as predictive biomarkers is still not a standard approach. Furthermore, only limited studies have investigated the expression of different subtypes of tyrosine kinase receptors on the protein level, especially on osteosarcoma (45-47,79-82). We do not know what kinds of TKIs showed more sensitivity and what kind of TKIs have more long-term lasting effectiveness based on those clinical trials. We may need to focus more on the $\mathrm{IC}_{50}$ values of specific subtypes of VEGFR and carry out more detailed work to choose appropriate targets for clinical use.

Twenty-five TKIs are currently FDA-approved and $>130$ are being evaluated in clinical trials (14). Increasing evidence suggests that drug exposure of TKIs may significantly contribute to drug resistance independently of somatic variation of TKI target genes. Membrane transport proteins may limit the amount of TKI reaching the target cells. In the early study of sunitinib on solid tumors, a decrease in the expression level of soluble VEGFR has been consistently reported (83). Conversely, an increased level of VEGF seems to occur and may have a role in the flare-up of tumor growth that may occur after sunitinib discontinuation (83). In addition, activation of alternative signaling pathways may overcome VEGFR inhibition. According to Loges et al (84), this reality depends on the mechanisms of refractoriness and evasive escape and the lack of well-validated biomarkers to monitor efficacy as well as optimal dosing or predict toxicity or resistance to VEGF-targeted therapy. Mutation of VEGFR/PDGFR or altered receptors or polymorphisms may also have a role in the resistance to anti-VEGF/VEGFR therapy (85). The resistance of this peripheral rim of viable tumor cells may be overcome by combination TKIs with targeted agents directed against kinases, such as mTOR, mitogen-activated protein kinases (MAPKs), and protein kinase C (PKC) or the addition of cytotoxic drugs to destroy sub-clones evading multi-targeted agents (65).
In addition to morphological differences, tumor endothelial cells have distinct gene expression profiles, which may also contribute to the resistance to antiangiogenic treatment strategies (6). Furthermore, the heterogeneity of cancer has often been a subject of interest and concern. DNA sequencing in a single tumor biopsy of 1 patient was not uniformly detectable throughout the sampling region (86). Such dynamic genomic changes in cancer cells are also expected to induce resistance in response to anti-angiogenesis drugs (87). The above explains why sorafenib only has the duration of response of 4 months while a combination with everolimus makes it 5 months $(12,13)$, which does not yet seems to be satisfactory for advanced patients. From these mechanisms, we can expect that combination therapy or sequencing therapy may benefit more people, which will be discussed later.

Toxicity. Compared with conventional chemotherapy, the toxicity and side effects of anti-angiogenesis TKIs are mild and can be tolerated by most heavily pre-treated advanced osteosarcoma patients. The most common toxicities are hypertension (grade 3 in approximately $10 \%$ patients), hand and foot syndrome, fatigue, proteinuria (usually grade 1-2), hemorrhage, arterial and venous thrombotic events (88), impaired wound healing, and occasionally gastrointestinal perforation (89), which was mostly observed in the initial phase II bevacizumab trials in ovarian cancer. VEGFR TKIs have also been associated with clinical hypothyroidism, which could be caused by the inhibition of iodine uptake in the thyroid (90). Some of those syndromes were reported to be related with better response and can be relieved gradually after months of therapy (88). However, combination therapy with multiple anti-angiogensis agents were considered to have more severe toxicity than some patients could tolerate (12). How to manage toxicity and efficiency is still a problem.

Evaluation systems. In addition to the challenge of identifying the most promising agents for clinical trials in osteosarcoma, obstacles inherent to this disease further complicate the successful design and completion of trials. In evaluating the efficacy of all the trials we have mentioned, the standard approach is to use imaging response criteria, such as response evaluation criteria in solid tumors 1.1 (RECIST 1.1) to compare the size and/or volume of lesion pretreatment and at regular intervals post-treatment (91). For a patient eligible for a trial using this approach, he or she must have measurable disease. However, as we mentioned before, angiogenesis inhibitors slowed or stopped tumor growth rather than causing the tumor's shrinkage (16).

Referring to most successful TKI therapy examples, such as renal cell carcinoma, GIST, or even soft tissue sarcoma, and considering with the characteristics of anti-angiogenesis TKIs, various new clinical evaluation systems have turned up, such as Choi (2009) (92), mChoi (2010) (93), SACT (2010) (94), and MASS (2010) (94). Nevertheless we cannot indiscriminately copy this evaluation. Because for unresectable primary osteosarcoma, which is located at the axial skeleton, for example, lesions mainly manifest as a bone lesion combined with or without soft tissue mass, which may not be evaluable according to these criteria. The lesion's shrinkage is originally not so obvious as other solid tumors. Besides, osteosarcoma is an osteogenic tumor that should not be evaluated by the 
M.D. Anderson system (95), which was developed to evaluate metastatic osteolytic lesions. All the above makes it even more complicated to assess the condition.

There are a few potential biomarkers in the blood that can be used to determine in vivo efficacy of anti-angiogenic treatment, i.e., VEGF-A, VEGF-B, and PIGF (96), circulating endothelial cells $(97,98)$, and even neutrophil-to-lymphocyte ratio (99). However, these biomarkers need to be studied further before they can be used in the clinic. In addition, functional imaging might be beneficial for evaluation, such as dynamic contrast-enhanced magnetic resonance imaging (DCE-MRI) (100), positron emission computed tomography (PET/CT) (101), and so on, which are under study and could make the prediction and monitoring of response more sensitive and ultimately lead to personalized anti-angiogenic treatment.

\section{Strategy for advanced osteosarcoma in the era of targeted therapy}

With the development of precision medicine, tremendous improvement has happened to traditional pathology. From the linking genomic and immunotherapy approaches to molecular subtype theory of Lim et al (102), we got to know that osteosarcoma has a more increased mutation burden than Ewing's sarcoma or synovial sarcoma, which is why it has not benefited from comprehensive molecular profiling $(103,104)$. Gerlinger et al (86) proposed the theory of intratumor heterogeneity and branched evolution of tumor cells in 2012, which made it even more difficult for the targeted therapy to maintain a long-term effect. Facing the intratumor heterogeneity at the genomic, epigenomic, and micro-environmental levels, the question is what is the optimal therapeutic option for these refractory groups.

Combination therapy, what we can do. The combination of anti-angiogenesis drugs with chemotherapy has been proposed for quite a while and has been verified in clinical trials of osteosarcoma with unfavorable results $(53,71)$ (Table III). It is a sound deduction that a treatment aimed at reducing the blood supply of a tumor would also reduce the delivery of any other therapy, such as chemotherapy, which is also important for radiotherapy for anti-angiogenesis agents and may reduce the oxygen supply necessary for a response to radiotherapy (16). However, synergism of anti-angiogenetics and chemotherapeutics has been observed in patients with colon cancers (105), non-small cell lung cancers (106), and breast cancers $(107,108)$. One explanation is that with the blockage of VEGF signaling, anti-angiogenetics induces a normalization of newly formed vessels, and thus, reduces the interstitial tissue pressure (ITP) within tumors, allowing enhanced delivery of chemotherapy to the tumors (7). However, advanced osteosarcoma usually has shown resistance to conventional chemotherapy. Secondline chemotherapy did not have much of an effect on these tumors, which makes the combination therapy not reasonable.

From the experience of Grignani et al (12), the multitargeted approach with TKIs or a combination of different pathway inhibitors seemed to have advantages in synergistic therapeutic effect and to overcome drug resistance. A disadvantage of using multi-targeted agents was that it might increase the toxicity and be difficult to determine which particular kinase inhibition results in an antitumor effect. Anyway, the prolonged time seemed not to be long enough to continue with a phase III trial (12). How to pick the appropriate drugs for combination therapy is still pending.

Sequencing therapy, timing, and strategy. Sequencing TKI therapy is a new concept for osteosarcoma. However, as for renal cell carcinoma (RCC) (109) and non-small cell lung cancer (110), it has been under discussion for a long time. At present, there is a strong rationale for sequencing targeted therapy for metastatic clear cell renal cancer (111), but the timing of the switch and the best agent to switch to remains unclear. Sunitinib and pazopanib are approved treatments in first-line therapy for patients with favorable or intermediate-risk clear cell RCC (112). Temsirolimus has been proven to be beneficial over interferon- $\alpha$ (IFN- $\alpha$ ) in patients with non-clear cell RCC (non-ccRCC) (113). Until recently, with regard to choosing the second-line treatment after the failure of therapy with VEGFR-TKIs, the continued inhibition of the VEGF/VEGR pathway or the switch to a mTOR inhibitor was controversial (114). These two options are characterized by partly different targets with completely different toxicity, but a comparable efficacy. This scenario changed dramatically, after the publication of 2 randomized, controlled, phase III trials, in which cabozantinib (115) and nivolumab (116) proved to be superior compared to everolimus. Regarding third-line treatment, where a sequence of 2 VEGFR-TKIs has been used beforehand, the choice is represented by the mTOR inhibitor everolimus, while if a VEGFR-TKI followed by everolimus is chosen, a return to VEGF pathway inhibition is suggested (112), which indicates the activation of different pathways might change during sequencing therapy and using targeted therapy back and forth may benefit drug-resistance patients and prolong survival. In the perspective of Maute et al (117), possible sequences include TKI-mTOR-TKI or TKI-TKI-mTOR with the upcoming checkpoint inhibitors in perspective, which might establish a new standard of care after previous TKI therapy.

However, for GIST, long-term follow-up results of the B2222 study and updated results of the BFR14 trial demonstrate that continuous imatinib treatment in patients with advanced GIST is associated with reduced risk of progression (118). For patients progressing on or intolerant of imatinib, continuing therapy with TKIs sunitinib followed by regorafenib is recommended (118), which seems to us a totally different strategy. For non-small cell lung cancer (NSCLC) therapy, the reversible epidermal growth factor receptor (EGFR) TKIs gefitinib and erlotinib have been proven to be the first-line therapy for NSCLC harboring activating EGFR mutations (119). Acquired resistance to EGFR TKIs is mainly mediated through 3 pathways: 1) activated EGFR family proteins and ligands, 2) activated various growth factor receptors, and 3) activated downstream signaling molecules (110). To explore the various proposed mechanisms of acquired resistance to EGFR-TKI therapy, agents that target secondary driving gene mutation as well as signaling pathways downstream of EGFR are being studied in molecularly selected advanced NSCLC (110), which, in a certain sense, formulates a more logical therapeutic strategy for advanced solid tumors. A degree of cross-resistance appears to exist between all of these current agents and has resulted in a drive toward the development of new therapies with novel modes of action (14). 


\section{Conclusion}

For advanced osteosarcoma, due to its increased mutation burden and intratumor heterogeneity, therapy based on comprehensive molecular profiling has not been successfully proven. At present, anti-angiogenesis TKIs showed promising initial results for this group of patients compared to other second-line chemotherapy, but the results are still not satisfactory. Based on the limited options of effective agents, the algorithm of choosing optimal target drugs is still understudied. The antiangiogenesis TKIs therapy of other solid tumors may shed light on the treatment for advanced OS.

\section{Acknowledgements}

We thank Dr Carola A.S. Arndt of Mayo Clinic Pediatric Oncology for her professional advice for the modification of this study.

\section{References}

1. Gorlick R, Anderson P, Andrulis I, Arndt C, Beardsley GP, Bernstein M, Bridge J, Cheung NK, Dome JS, Ebb D, et al: Biology of childhood osteogenic sarcoma and potential targets for therapeutic development: meeting summary. Clin Cancer Res 9: 5442-5453, 2003.

2. van Maldegem AM, Bhosale A, Gelderblom HJ, Hogendoorn PC and Hassan AB: Comprehensive analysis of published phase I/II clinical trials between 1990-2010 in osteosarcoma and Ewing sarcoma confirms limited outcomes and need for translational investment. Clin Sarcoma Res 2: 5, 2012.

3. Dickerson ME, Page RL, LaDue TA, Hauck ML, Thrall DE, Stebbins ME and Price GS: Retrospective analysis of axial skeleton osteosarcoma in 22 large-breed dogs. J Vet Intern Med 15: 120-124, 2001.

4. Lagmay JP, Krailo MD, Dang H, Kim A, Hawkins DS, Beaty O III, Widemann BC, Zwerdling T, Bomgaars L, Langevin AM, et al: Outcome of patients with recurrent osteosarcoma enrolled in seven phase II trials through children's cancer group, pediatric oncology group, and children's oncology group: Learning from the past to move forward. J Clin Oncol 34: 3031-3038, 2016.

5. Mac Gabhann F, Qutub AA, Annex BH and Popel AS: Systems biology of pro-angiogenic therapies targeting the VEGF system. Wiley Interdiscip Rev Syst Biol Med 2: 694-707, 2010.

6. Versleijen-Jonkers YM, Vlenterie M, van de Luijtgaarden AC and van der Graaf WT: Anti-angiogenic therapy, a new player in the field of sarcoma treatment. Crit Rev Oncol Hematol 91: 172-185, 2014.

7. Quan GM and Choong PF: Anti-angiogenic therapy for osteosarcoma. Cancer Metastasis Rev 25: 707-713, 2006.

8. DuBois S and Demetri G: Markers of angiogenesis and clinical features in patients with sarcoma. Cancer 109: 813-819, 2007.

9. Segal E, Pan H, Ofek P, Udagawa T, Kopecková P, Kopecek J and Satchi-Fainaro R: Targeting angiogenesis-dependent calcified neoplasms using combined polymer therapeutics. PLoS One 4: e5233, 2009.

10. van Cruijsen H, Voest EE, Punt CJ, Hoekman K, Witteveen PO, Meijerink MR, Puchalski TA, Robertson J, Saunders O, Jürgensmeier JM, et al: Phase I evaluation of cediranib, a selective VEGFR signalling inhibitor, in combination with gefitinib in patients with advanced tumours. Eur J Cancer 46: 901-911, 2010.

11. Schuetze SM, Wathen JK, Lucas DR, Choy E, Samuels BL, Staddon AP, Ganjoo KN, von Mehren M, Chow WA, Loeb DM, et al: SARC009: Phase 2 study of dasatinib in patients with previously treated, high-grade, advanced sarcoma. Cancer 122 868-874, 2016

12. Grignani G, Palmerini E, Ferraresi V, D'Ambrosio L, Bertulli R, Asaftei SD, Tamburini A, Pignochino Y, Sangiolo D, Marchesi E, et al; Italian Sarcoma Group: Sorafenib and everolimus for patients with unresectable high-grade osteosarcoma progressing after standard treatment: A non-randomised phase 2 clinical trial. Lancet Oncol 16: 98-107, 2015.
13. Grignani G, Palmerini E, Dileo P, Asaftei SD, D'Ambrosio L, Pignochino Y, Mercuri M, Picci P, Fagioli F, Casali PG, et al: A phase II trial of sorafenib in relapsed and unresectable highgrade osteosarcoma after failure of standard multimodal therapy: an Italian Sarcoma Group study. Ann Oncol 23: 508-516, 2012.

14. Neul C, Schaeffeler E, Sparreboom A, Laufer S, Schwab M and Nies AT: Impact of membrane drug transporters on resistance to small-molecule tyrosine kinase inhibitors. Trends Pharmacol Sci 37: 904-932, 2016.

15. Carmeliet P: Angiogenesis in life, disease and medicine. Nature 438: 932-936, 2005.

16. Niu G and Chen X: Vascular endothelial growth factor as an anti-angiogenic target for cancer therapy. Curr Drug Targets 11: 1000-1017, 2010

17. Steeghs N, Nortier JW and Gelderblom H: Small molecule tyrosine kinase inhibitors in the treatment of solid tumors: An update of recent developments. Ann Surg Oncol 14: 942-953, 2007.

18. Kuhnen C, Lehnhardt M, Tolnay E, Muehlberger T, Vogt PM and Müller KM: Patterns of expression and secretion of vascular endothelial growth factor in malignant soft-tissue tumours. J Cancer Res Clin Oncol 126: 219-225, 2000.

19. Potti A, Ganti AK, Tendulkar K, Sholes K, Chitajallu S, Koch M and Kargas S: Determination of vascular endothelial growth factor (VEGF) overexpression in soft tissue sarcomas and the role of overexpression in leiomyosarcoma. J Cancer Res Clin Oncol 130: 52-56, 2004.

20. Fuchs B, Inwards CY and Janknecht R: Vascular endothelial growth factor expression is up-regulated by EWS-ETS oncoproteins and Sp1 and may represent an independent predictor of survival in Ewing's sarcoma. Clin Cancer Res 10: 1344-1353, 2004.

21. Gee MF, Tsuchida R, Eichler-Jonsson C, Das B, Baruchel S and Malkin D: Vascular endothelial growth factor acts in an autocrine manner in rhabdomyosarcoma cell lines and can be inhibited with all-trans-retinoic acid. Oncogene 24: 8025-8037, 2005.

22. Su JL, Yen CJ, Chen PS, Chuang SE, Hong CC, Kuo IH, Chen HY, Hung MC and Kuo ML: The role of the VEGF-C/VEGFR-3 axis in cancer progression. Br J Cancer 96: 541-545, 2007.

23. Waltenberger J, Claesson-Welsh L, Siegbahn A, Shibuya M and Heldin $\mathrm{CH}$ : Different signal transduction properties of KDR and Flt1, two receptors for vascular endothelial growth factor. J Biol Chem 269: 26988-26995, 1994.

24. Agulnik M, Yarber JL, Okuno SH, von Mehren M, Jovanovic BD, Brockstein BE, Evens AM and Benjamin RS: An open-label, multicenter, phase II study of bevacizumab for the treatment of angiosarcoma and epithelioid hemangioendotheliomas. Ann Oncol 24: 257-263, 2013.

25. Watanabe H, Mamelak AJ, Wang B, Howell BG, Freed I, Esche C, Nakayama M, Nagasaki G, Hicklin DJ, Kerbel RS, et al: Anti-vascular endothelial growth factor receptor-2 (Flk-1/KDR) antibody suppresses contact hypersensitivity. Exp Dermatol 13: 671-681, 2004.

26. Ciardiello F, Caputo R, Damiano V, Caputo R, Troiani T, Vitagliano D, Carlomagno F, Veneziani BM, Fontanini G, Bianco AR, et al: Antitumor effects of ZD6474, a small molecule vascular endothelial growth factor receptor tyrosine kinase inhibitor, with additional activity against epidermal growth factor receptor tyrosine kinase. Clin Cancer Res 9: 1546-1556, 2003.

27. Trippett TM, Herzog C, Whitlock JA, Wolff J, Kuttesch J, Bagatell R, Hunger SP, Boklan J, Smith AA, Arceci RJ, et al: Phase I and pharmacokinetic study of cetuximab and irinotecan in children with refractory solid tumors: A study of the pediatric oncology experimental therapeutic investigators' consortium. J Clin Oncol 27: 5102-5108, 2009.

28. Navid F, Baker SD, McCarville MB, Stewart CF, Billups CA Wu J, Davidoff AM, Spunt SL, Furman WL, McGregor LM, et al: Phase I and clinical pharmacology study of bevacizumab, sorafenib, and low-dose cyclophosphamide in children and young adults with refractory/recurrent solid tumors. Clin Cancer Res 19: 236-246, 2013.

29. Malempati S, Weigel B, Ingle AM, Ahern CH, Carroll JM, Roberts CT, Reid JM, Schmechel S, Voss SD, Cho SY, et al: Phase I/II trial and pharmacokinetic study of cixutumumab in pediatric patients with refractory solid tumors and Ewing sarcoma: A report from the Children's Oncology Group. J Clin Oncol 30: 256-262, 2012. 
30. KerklaanBM,LolkemaMP,Devriese LA,VoestEE,Nol-Boekel A Mergui-Roelvink M, Langenberg M, Mykulowycz K, Stoebenau J, Lane S, et al: Phase I and pharmacological study of pazopanib in combination with oral topotecan in patients with advanced solid tumours. Br J Cancer 113: 706-715, 2015.

31. Inada-Inoue M, Ando Y, Kawada K, Mitsuma A, Sawaki M, Yokoyama T, Sunakawa Y, Ishida H, Araki K, Yamashita K, et al: Phase 1 study of pazopanib alone or combined with lapatinib in Japanese patients with solid tumors. Cancer Chemother Pharmacol 73: 673-683, 2014.

32. Glade Bender JL, Lee A, Reid JM, Baruchel S, Roberts T, Voss $\mathrm{SD}, \mathrm{Wu} \mathrm{B}, \mathrm{Ahern} \mathrm{CH}$, Ingle AM, Harris $\mathrm{P}$, et al: Phase I pharmacokinetic and pharmacodynamic study of pazopanib in children with soft tissue sarcoma and other refractory solid tumors: A children's oncology group phase I consortium report. J Clin Oncol 31: 3034-3043, 2013.

33. Glade Bender JL, Adamson PC, Reid JM, Xu L, Baruchel S, Shaked Y, Kerbel RS, Cooney-Qualter EM, Stempak D, Chen HX, et al; Children's Oncology Group Study: Phase I trial and pharmacokinetic study of bevacizumab in pediatric patients with refractory solid tumors: A Children's Oncology Group Study. J Clin Oncol 26: 399-405, 2008.

34. Freeman BB III, Daw NC, Geyer JR, Furman WL and Stewart CF: Evaluation of gefitinib for treatment of refractory solid tumors and central nervous system malignancies in pediatric patients. Cancer Invest 24: 310-317, 2006.

35. Fox E, Aplenc R, Bagatell R, Chuk MK, Dombi E, Goodspeed W, Goodwin A, Kromplewski M, Jayaprakash N, Marotti M, et al: A phase 1 trial and pharmacokinetic study of cediranib, an orally bioavailable pan-vascular endothelial growth factor receptor inhibitor, in children and adolescents with refractory solid tumors. J Clin Oncol 28: 5174-5181, 2010.

36. Dubois SG, Shusterman S, Ingle AM, Ahern CH, Reid JM, Wu B, Baruchel S, Glade-Bender J, Ivy P, Grier HE, et al: Phase I and pharmacokinetic study of sunitinib in pediatric patients with refractory solid tumors: a children's oncology group study. Clin Cancer Res 17: 5113-5122, 2011.

37. Daw NC, Furman WL, Stewart CF, Iacono LC, Krailo M, Bernstein ML, Dancey JE, Speights RA, Blaney SM, Croop JM, et al; Children's Oncology Group: Phase I and pharmacokinetic study of gefitinib in children with refractory solid tumors: A Children's Oncology Group Study. J Clin Oncol 23: 6172-6180, 2005

38. Brell JM, Krishnamurthi SS, Rath L, Bokar JA, Savvides P, Gibbons J, Cooney MM, Meropol NJ, Ivy P and Dowlati A: Phase I trial of sunitinib and gemcitabine in patients with advanced solid tumors. Cancer Chemother Pharmacol 70: 547-553, 2012.

39. BagatellR,Herzog CE,TrippettTM,Grippo JF, Cirrincione-Dall G, Fox E, Macy M, Bish J, Whitcomb P, Aikin A, et al: Pharmacokinetically guided phase 1 trial of the IGF-1 receptor antagonist RG1507 in children with recurrent or refractory solid tumors. Clin Cancer Res 17: 611-619, 2011.

40. Broadhead ML, Choong PF and Dass CR: Efficacy of continuously administered PEDF-derived synthetic peptides against osteosarcoma growth and metastasis. J Biomed Biotechnol 2012: 230298, 2012.

41. Takenaka K, Yamagishi S, Jinnouchi Y, Nakamura K, Matsui T and Imaizumi T: Pigment epithelium-derived factor (PEDF)induced apoptosis and inhibition of vascular endothelial growth factor (VEGF) expression in MG63 human osteosarcoma cells Life Sci 77: 3231-3241, 2005.

42. Ek ET, Dass CR, Contreras KG and Choong PF: PEDF-derived synthetic peptides exhibit antitumor activity in an orthotopic model of human osteosarcoma. J Orthop Res 25: 1671-1680, 2007.

43. Dass CR, Ek ET and Choong PF: PEDF as an emerging therapeutic candidate for osteosarcoma. Curr Cancer Drug Targets 8: 683-690, 2008

44. Geller DS and Gorlick R: HER-2 targeted treatment of osteosarcoma: The challenges of developing targeted therapy and prognostic factors for rare malignancies. Expert Opin Pharmacother 11: 51-61, 2010.

45. Abdeen A, Chou AJ, Healey JH, Khanna C, Osborne TS, Hewitt SM, Kim M, Wang D, Moody K and Gorlick R: Correlation between clinical outcome and growth factor pathway expression in osteogenic sarcoma. Cancer 115: 5243-5250, 2009.

46. Yang J, Yang D, Sun Y, Sun B, Wang G, Trent JC, Araujo DM, Chen $\mathrm{K}$ and Zhang W: Genetic amplification of the vascular endothelial growth factor (VEGF) pathway genes, including VEGFA, in human osteosarcoma. Cancer 117: 4925-4938, 2011.
47. Lammli J, Fan M, Rosenthal HG, Patni M, Rinehart E, Vergara G, Ablah E, Wooley PH, Lucas G and Yang SY: Expression of vascular endothelial grow th factor correlates with the advance of clinical osteosarcoma. Int Orthop 36: 2307-2313, 2012.

48. Chen D, Zhang YJ, Zhu KW and Wang WC: A systematic review of vascular endothelial growth factor expression as a biomarker of prognosis in patients with osteosarcoma. Tumour Biol 34: 1895-1899, 2013

49. Kampmann E, Altendorf-Hofmann A, Gibis S, Lindner LH, Issels R, Kirchner T and Knösel T: VEGFR2 predicts decreased patients survival in soft tissue sarcomas. Pathol Res Pract 211: 726-730, 2015.

50. Aubry K, Barriere G, Chable-Rabinovitch H, Dutour A, Paraf F, Monteil J and Rigaud M: Molecular mechanisms regulating the angiogenic phenotype in tumors: Clinical impact in the future. Anticancer Res 27: 3111-3119, 2007.

51. O'Reilly MS, Boehm T, Shing Y, Fukai N, Vasios G, Lane WS, Flynn E, Birkhead JR, Olsen BR and Folkman J: Endostatin: An endogenous inhibitor of angiogenesis and tumor growth. Cell 88: 277-285, 1997.

52. Nalluri SR, Chu D, Keresztes R, Zhu X and Wu S: Risk of venous thromboembolism with the angiogenesis inhibitor bevacizumab in cancer patients: A meta-analysis. JAMA 300: 2277-2285, 2008.

53. Ebb D, Meyers P, Grier H, Bernstein M, Gorlick R, Lipshultz SE, Krailo M, Devidas M, Barkauskas DA, Siegal GP, et al: Phase II trial of trastuzumab in combination with cytotoxic chemotherapy for treatment of metastatic osteosarcoma with human epidermal growth factor receptor 2 overexpression: A report from the Children's Oncology Group. J Clin Oncol 30: 2545-2551, 2012.

54. Wildiers H, Guetens G, De Boeck G, Verbeken E, Landuyt B, Landuyt W, de Bruijn EA and van Oosterom AT: Effect of antivascular endothelial growth factor treatment on the intratumoral uptake of CPT-11. Br J Cancer 88: 1979-1986, 2003.

55. White RR, Sullenger BA and Rusconi CP: Developing aptamers into therapeutics. J Clin Invest 106: 929-934, 2000.

56. Holash J, Davis S, Papadopoulos N, Croll SD, Ho L, Russell M, Boland P, Leidich R, Hylton D, Burova E, et al: VEGF-Trap: A VEGF blocker with potent antitumor effects. Proc Natl Acad Sci USA 99: 11393-11398, 2002.

57. Blume-Jensen $P$ and Hunter T: Oncogenic kinase signalling. Nature 411: 355-365, 2001.

58. Ségaliny AI, Tellez-Gabriel M, Heymann MF and Heymann D: Receptor tyrosine kinases: Characterisation, mechanism of action and therapeutic interests for bone cancers. J Bone Oncol 4: 1-12, 2015.

59. Pignochino Y, Grignani G, Cavalloni G, Motta M, Tapparo M, Bruno S, Bottos A, Gammaitoni L, Migliardi G, Camussi G, et al: Sorafenib blocks tumour growth, angiogenesis and metastatic potential in preclinical models of osteosarcoma through a mechanism potentially involving the inhibition of ERK1/2, MCL-1 and ezrin pathways. Mol Cancer 8: 118, 2009.

60. Wolfesberger B, Tonar Z, Gerner W, Skalicky M, Heiduschka G, Egerbacher M, Thalhammer JG and Walter I: The tyrosine kinase inhibitor sorafenib decreases cell number and induces apoptosis in a canine osteosarcoma cell line. Res Vet Sci 88: 94-100, 2010.

61. Safwat A, Boysen A, Lücke A and Rossen P: Pazopanib in metastatic osteosarcoma: Significant clinical response in three consecutive patients. Acta Oncol 53: 1451-1454, 2014.

62. Lu D, Jimenez X, Zhang H, Bohlen P, Witte L and Zhu Z: Selection of high affinity human neutralizing antibodies to VEGFR2 from a large antibody phage display library for antiangiogenesis therapy. Int J Cancer 97: 393-399, 2002.

63. O'Day K and Gorlick R: Novel therapeutic agents for osteosarcoma. Expert Rev Anticancer Ther 9: 511-523, 2009.

64. Hanahan D and Weinberg RA: Hallmarks of cancer: The next generation. Cell 144: 646-674, 2011.

65. Chandhanayingyong C, Kim Y, Staples JR, Hahn C and Lee FY: MAPK/ERK Signaling in osteosarcomas, ewing sarcomas and chondrosarcomas: Therapeutic implications and future directions. Sarcoma 2012: 404810, 2012.

66. Allen E, Miéville P, Warren CM, Saghafinia S, Li L, Peng MW and Hanahan D: Metabolic symbiosis enables adaptive resistance to anti-angiogenic therapy that is dependent on mTOR signaling. Cell Rep 15: 1144-1160, 2016.

67. Weigel B, Malempati S, Reid JM, Voss SD, Cho SY, Chen HX, Krailo M, Villaluna D, Adamson PC and Blaney SM: Phase 2 trial of cixutumumab in children, adolescents, and young adults with refractory solid tumors: A report from the Children's Oncology Group. Pediatr Blood Cancer 61: 452-456, 2014. 
68. Wagner LM, Fouladi M, Ahmed A, Krailo MD, Weigel B, DuBois SG, Doyle LA, Chen H and Blaney SM: Phase II study of cixutumumab in combination with temsirolimus in pediatric patients and young adults with recurrent or refractory sarcoma: A report from the Children's Oncology Group. Pediatr Blood Cancer 62: 440-444, 2015.

69. Kempf-Bielack B, Bielack SS, Jürgens H, Branscheid D, Berdel WE, Exner GU, Göbel U, Helmke K, Jundt G, Kabisch H, et al: Osteosarcoma relapse after combined modality therapy: An analysis of unselected patients in the Cooperative Osteosarcoma Study Group (COSS). J Clin Oncol 23: 559-568, 2005.

70. Steliga M and Vaporciyan A: Surgical treatment of pulmonary metastases from osteosarcoma in pediatric and adolescent patients. Cancer Treat Res 152: 185-201, 2009.

71. Schuetze SM, Zhao L, Chugh R, Thomas DG, Lucas DR, Metko G, Zalupski MM and Baker LH: Results of a phase II study of sirolimus and cyclophosphamide in patients with advanced sarcoma. Eur J Cancer 48: 1347-1353, 2012.

72. Demetri GD, Chawla SP, Ray-Coquard I, Le Cesne A, Staddon AP, Milhem MM, Penel N, Riedel RF, Bui-Nguyen B, Cranmer LD, et al: Results of an international randomized phase III trial of the mammalian target of rapamycin inhibitor ridaforolimus versus placebo to control metastatic sarcomas in patients after benefit from prior chemotherapy. J Clin Oncol 31: 2485-2492, 2013.

73. Chawla SP, Staddon AP, Baker LH, Schuetze SM, Tolcher AW, D'Amato GZ, Blay JY, Mita MM, Sankhala KK, Berk L, et al: Phase II study of the mammalian target of rapamycin inhibitor ridaforolimus in patients with advanced bone and soft tissue sarcomas. J Clin Oncol 30: 78-84, 2012.

74. Schwartz GK, Tap WD, Qin LX, Livingston MB, Undevia SD Chmielowski B, Agulnik M, Schuetze SM, Reed DR, Okuno SH, et al: Cixutumumab and temsirolimus for patients with bone and soft-tissue sarcoma: A multicentre, open-label, phase 2 trial. Lancet Oncol 14: 371-382, 2013.

75. Reed DR, Mascarenhas L, Manning K, Hale GA, Goldberg J, Gill J, Sandler E, Isakoff MS, Smith T, Caracciolo J, et al: Pediatric phase I trial of oral sorafenib and topotecan in refractory or recurrent pediatric solid malignancies. Cancer Med 5: 294-303, 2016

76. Quek R, Wang Q, Morgan JA, Shapiro GI, Butrynski JE, Ramaiya N, Huftalen T, Jederlinic N, Manola J, Wagner AJ, et al: Combination mTOR and IGF-1R inhibition: phase I trial of everolimus and figitumumab in patients with advanced sarcomas and other solid tumors. Clin Cancer Res 17: 871-879, 2011.

77. Pappo AS, Vassal G, Crowley JJ, Bolejack V, Hogendoorn PC, Chugh R, Ladanyi M, Grippo JF, Dall G, Staddon AP, et al: A phase 2 trial of R1507, a monoclonal antibody to the insulin-like growth factor-1 receptor (IGF-1R), in patients with recurrent or refractory rhabdomyosarcoma, osteosarcoma, synovial sarcoma, and other soft tissue sarcomas: Results of a Sarcoma Alliance for Research Through Collaboration study. Cancer 120: 2448-2456, 2014.

78. Olmos D, Postel-Vinay S, Molife LR, Okuno SH, Schuetze SM, Paccagnella ML, Batzel GN, Yin D, Pritchard-Jones K, Judson I, et al: Safety, pharmacokinetics, and preliminary activity of the anti-IGF-1R antibody figitumumab (CP-751,871) in patients with sarcoma and Ewing's sarcoma: A phase 1 expansion cohort study. Lancet Oncol 11: 129-135, 2010.

79. Hassan SE, Bekarev M, Kim MY, Lin J, Piperdi S, Gorlick R and Geller DS: Cell surface receptor expression patterns in osteosarcoma. Cancer 118: 740-749, 2012

80. Freeman SS, Allen SW, Ganti R, Wu J, Ma J, Su X, Neale G, Dome JS, Daw NC and Khoury JD: Copy number gains in EGFR and copy number losses in PTEN are common events in osteosarcoma tumors. Cancer 113: 1453-1461, 2008.

81. Roth M, Linkowski M, Tarim J, Piperdi S, Sowers R, Geller D, Gill J and Gorlick R: Ganglioside GD2 as a therapeutic targe for antibody-mediated therapy in patients with osteosarcoma. Cancer 120: 548-554, 2014.

82. Kubo T, Piperdi S, Rosenblum J, Antonescu CR, Chen W, Kim HS, Huvos AG, Sowers R, Meyers PA, Healey JH, et al: Platelet-derived growth factor receptor as a prognostic marker and a therapeutic target for imatinib mesylate therapy in osteosarcoma. Cancer 112: 2119-2129, 2008.

83. Ebos JM, Lee CR, Christensen JG, Mutsaers AJ and Kerbel RS Multiple circulating proangiogenic factors induced by sunitinib malate are tumor-independent and correlate with antitumor efficacy. Proc Natl Acad Sci USA 104: 17069-17074, 2007.
84.Loges S, Schmidt T and Carmeliet P: Mechanisms of resistance to anti-angiogenic therapy and development of third-generation anti-angiogenic drug candidates. Genes Cancer 1: 12-25, 2010.

85. Casanovas O, Hicklin DJ, Bergers G and Hanahan D: Drug resistance by evasion of antiangiogenic targeting of VEGF signaling in late-stage pancreatic islet tumors. Cancer Cell 8: 299-309, 2005

86. Gerlinger M, Rowan AJ, Horswell S, Larkin J, Endesfelder D, Gronroos E, Martinez P, Matthews N, Stewart A, Tarpey P, et al: Intratumor heterogeneity and branched evolution revealed by multiregion sequencing. N Engl J Med 366: 883-892, 2012.

87. Seoane $\mathbf{J}$ and De Mattos-Arruda L: The challenge of intratumour heterogeneity in precision medicine. J Intern Med 276: 41-51, 2014.

88. Massey PR, Okman JS, Wilkerson J and Cowen EW: Tyrosine kinase inhibitors directed against the vascular endothelial growth factor receptor (VEGFR) have distinct cutaneous toxicity profiles: A meta-analysis and review of the literature. Support Care Cancer 23: 1827-1835, 2015.

89. Hurwitz H: Integrating the anti-VEGF-A humanized monoclonal antibody bevacizumab with chemotherapy in advanced colorectal cancer. Clin Colorectal Cancer 4 (Suppl 2): S62-S68, 2004.

90. Eskens FA and Verweij J: The clinical toxicity profile of vascular endothelial growth factor (VEGF) and vascular endothelial growth factor receptor (VEGFR) targeting angiogenesis inhibitors; a review. Eur J Cancer 42: 3127-3139, 2006.

91. Costelloe CM, Chuang HH, Madewell JE and Ueno NT: Cancer Response Criteria and Bone Metastases: RECIST 1.1, MDA and PERCIST. J Cancer 1: 80-92, 2010.

92. Stacchiotti S, Collini P, Messina A, Morosi C, Barisella M, Bertulli R, Piovesan C, Dileo P, Torri V, Gronchi A, et al: High-grade soft-tissue sarcomas: Tumor response assessment pilot study to assess the correlation between radiologic and pathologic response by using RECIST and Choi criteria. Radiology 251: 447-456, 2009.

93. Nathan PD, Vinayan A, Stott D, Juttla J and Goh V: CT response assessment combining reduction in both size and arterial phase density correlates with time to progression in metastatic renal cancer patients treated with targeted therapies. Cancer Biol Ther 9: $15-19,2010$

94. Fournier L, Ammari S, Thiam R and Cuénod CA: Imaging criteria for assessing tumour response: RECIST, mRECIST, Cheson. Diagn Interv Imaging 95: 689-703, 2014.

95. Hamaoka T, Madewell JE, Podoloff DA, Hortobagyi GN and Ueno NT: Bone imaging in metastatic breast cancer. J Clin Oncol 22: 2942-2953, 2004

96. Pakos EE and Ioannidis JP: The association of P-glycoprotein with response to chemotherapy and clinical outcome in patients with osteosarcoma. A meta-analysis. Cancer 98: 581-589, 2003.

97. Jakubowska A, Rozkrut D, Antoniou A, Hamann U, Scott RJ, McGuffog L, Healy S, Sinilnikova OM, Rennert G,Lejbkowicz F, et al; OCGN; SWE-BRCA; HEBON; EMBRACE; GEMO Study Collaborators; KConFab; CIMBA, the Consortium of Investigators of Modifiers of BRCA1/2-Related Cancer: Association of PHB $1630 \mathrm{C}>\mathrm{T}$ and MTHFR $677 \mathrm{C}>\mathrm{T}$ polymorphisms with breast and ovarian cancer risk in BRCA1/2 mutation carriers: Results from a multicenter study. Br J Cancer 106: 2016-2024, 2012.

98.Zurita AJ, Jonasch E, Wu HK, Tran HT and Heymach JV: Circulating biomarkers for vascular endothelial growth factor inhibitors in renal cell carcinoma. Cancer 115 (Suppl 10): 2346-2354, 2009

99. Ahbap E, Sakaci T, Kara E, Sahutoglu T, Koc Y, Basturk T, Sevinc M, Akgol C, Kayalar AO, Ucar ZA, et al: Neutrophil-tolymphocyte ratio and platelet-tolymphocyte ratio in evaluation of inflammation in end-stage renal disease. Clin Nephrol 85 199-208, 2016

100. Jaffe N, Keifer R III, Robertson R, Cangir A and Wang A: Renal toxicity with cumulative doses of cis-diamminedichloroplatinum-II in pediatric patients with osteosarcoma. Effect on creatinine clearance and methotrexate excretion. Cancer 59: $1577-1581,1987$.

101. Aras M, Erdil TY, Dane F, Gungor S, Ones T, Dede F, Inanir S and Turoglu HT: Comparison of WHO, RECIST 1.1, EORTC, and PERCIST criteria in the evaluation of treatment response in malignant solid tumors. Nucl Med Commun 37: 9-15, 2016.

102.Lim J, Poulin NM and Nielsen TO: New strategies in sarcoma: linking genomic and immunotherapy approaches to molecular subtype. Clin Cancer Res 21: 4753-4759, 2015. 
103. Subbiah V, Wagner MJ, McGuire MF, Sarwari NM, Devarajan E Lewis VO, Westin S, Kato S, Brown RE and Anderson P: Personalized comprehensive molecular profiling of high risk osteosarcoma: Implications and limitations for precision medicine. Oncotarget 6: 40642-40654, 2015.

104.Egas-Bejar D, Anderson PM, Agarwal R, Corrales-Medina F, Devarajan E, Huh WW, Brown RE and Subbiah V: Theranostic profiling for actionable aberrations in advanced high risk osteosarcoma with aggressive biology reveals high molecular diversity: The human fingerprint hypothesis. Oncoscience 1: 167-179, 2014.

105. Hurwitz H, Fehrenbacher L, Novotny W, Cartwright T, Hainsworth J, Heim W, Berlin J, Baron A, Griffing S, Holmgren E, et al: Bevacizumab plus irinotecan, fluorouracil, and leucovorin for metastatic colorectal cancer. N Engl J Med 350: 2335-2342, 2004

106. Sandler A, Gray R, Perry MC, Brahmer J, Schiller JH, Dowlati A, Lilenbaum R and Johnson DH: Paclitaxel-carboplatin alone or with bevacizumab for non-small-cell lung cancer. N Engl J Med 355: 2542-2550, 2006.

107. Nerich V, Chelly J, Montcuquet P, Chaigneau L, Villanueva C, Fiteni F, Meneveau N, Perrin S, Voidey A, Monnot T, et al: First-line trastuzumab plus taxane-based chemotherapy for metastatic breast cancer: Cost-minimization analysis. J Oncol Pharm Pract 20: 362-368, 2014.

108. Cheng YC, Rondón G, Anderlini P, Khouri IF, Champlin RE and Ueno NT: Paclitaxel and trastuzumab as maintenance therapy in patients with HER2-positive metastatic breast cancer who underwent high-dose chemotherapy and autologous hematopoietic stem cell transplantation. J Cancer 4: 679-685, 2013

109. Powles T and Crusz SM: Sequencing systemic therapies in advanced RCC: Is there a best strategy? Am Soc Clin Oncol Educ Book 33: e172-e174, 2013.

110. Kuwano M, Sonoda K, Murakami Y, Watari K and Ono M: Overcoming drug resistance to receptor tyrosine kinase inhibitors: Learning from lung cancer. Pharmacol Ther 161: 97-110, 2016.
111. Porta C, Giglione P and Paglino C: Targeted therapy for renal cell carcinoma: Focus on 2nd and 3rd line. Expert Opin Pharmacother 17: 643-655, 2016.

112. Kim SH, Park WS, Kim SH, Joung JY, Seo HK, Lee KH and Chung J: Systemic treatments for metastatic renal cell carcinoma: 10-Year experience of immunotherapy and targeted therapy. Cancer Res Treat 48: 1092-1101, 2016.

113. Kramer MW, Steffens S, von Klot C, Merseburger AS and Kuczyk MA: Systemic therapy for metastatic renal cell carcinoma. Aktuelle Urol 43: 265-268, 2012 (In German).

114. Buti S, Leonetti A, Dallatomasina A and Bersanelli $M$ Everolimus in the management of metastatic renal cell carcinoma: An evidence-based review of its place in therapy. Core Evid 11: 23-36, 2016.

115. Choueiri TK, Escudier B, Powles T, Tannir NM, Mainwaring PN, Rini BI, Hammers HJ, Donskov F, Roth BJ, Peltola K, et al; METEOR investigators: Cabozantinib versus everolimus in advanced renal cell carcinoma (METEOR): Final results from a randomised, open-label, phase 3 trial. Lancet Oncol 17: 917-927, 2016.

116. Cella D, Grünwald V, Nathan P, Doan J, Dastani H, Taylor F, Bennett B, DeRosa M, Berry S, Broglio K, et al: Quality of life in patients with advanced renal cell carcinoma given nivolumab versus everolimus in CheckMate 025: A randomised, openlabel, phase 3 trial. Lancet Oncol 17: 994-1003, 2016.

117. Maute L and Bergmann L: Systemic therapy of metastatic renal cell carcinoma. Dtsch Med Wochenschr 141: 466-469, 2016 (In German)

118. Le Cesne A, Blay JY, Reichardt P and Joensuu H: Optimizing tyrosine kinase inhibitor therapy in gastrointestinal stromal tumors: Exploring the benefits of continuous kinase suppression. Oncologist 18: 1192-1199, 2013.

119. Shien K, Yamamoto H, Soh J, Miyoshi S and Toyooka S: Drug resistance to EGFR tyrosine kinase inhibitors for non-small cell lung cancer. Acta Med Okayama 68: 191-200, 2014 